\title{
Cytotaxonomical Studies of South Indian Scrophulariaceae
}

\author{
D. Subramanian and R. Pondmudi \\ Department of Botany, Annamalai University, \\ Annamalainagar-608002, Tamilnadu, India
}

Accepted May 10, 1986

The Scrophulariaceae consists of about 210 genera and nearly 3000 species of cosmopolitan distribution and represents on all continents (Lawrence 1966). In South India, there are about 38 genera including 87 species of Scrophulariaceae discribed by Gamble (1956). Apart from these wild species, there are cultivated, medicinal and ornamental species like Digitalis purpurea, Antirrhinum majus, Angelonia grandiflora, Linaria vulgaris, Russelia juncea and Torenia fournieri found in the plains as well as hill stations like Ooty, Kodaikanal and Yercuad. 21 species coming under 19 genera have been included in the present investigation. In most of the species studied there are no detailed studies and therefore, the present investigation has been undertaken. Evenwhere the chromosome numbers have been determined (Fedorov 1974), the knowledge concerning the details of karyotype pertaining to chromosome measurements, which are vital to the understanding of karyological affinities is still meagre.

\section{Materials and methods}

The particulars about the species studied, places of collection and wild or cultivated are furnished in Table 1. All these species were grown in 1' clay pots under identical conditions under shade in our Botanical Garden, Annamalai University.

Young and healthy root tips were collected and pretreated in $0.02 \%$ hydroxyquinoline kept

Table 1.

\begin{tabular}{|c|c|c|c|}
\hline $\begin{array}{l}\text { S. } \\
\text { no. }\end{array}$ & Species studied & $\begin{array}{l}\text { Wild or } \\
\text { cultivated }\end{array}$ & Place of collection \\
\hline 1 & Verbascum thapsus $\mathrm{L}$. & Wild & Ooty \\
\hline 2 & Celsia coromandeliana Vahl. & Wild & Annamalainagar \\
\hline 3 & Linaria vulgaris (L.) Mill. & Cultivated & Kodaikanal \\
\hline 4 & Stemodia viscosa Roxb. & Wild & Annamalainagar \\
\hline 5 & Lymnophila heterophylla Benth. & Wild & Annamalainagar \\
\hline 6 & Moniera cuneifolia Mich. & Wild & Annamalainagar \\
\hline 7 & Dopatrium lobelioides Benth. & Wild & Annamalainagar \\
\hline 8 & Torenia fournieri Linden & Cultivated & Madras, Soundarya Nurseries \\
\hline 9 & Vandellia crustacea Benth. & Wild & Annamalainagar \\
\hline 10 & Ilysanthes tenuifolia Urban & Wild & Kille \\
\hline 11 & 1. oppositifolia Urban & Wild & Virudhachalam \\
\hline 12 & Scoparia dulcis L. & Wild & Annamalainagar \\
\hline 13 & Sopubia trifida Ham. & Wild & Kodaikanal \\
\hline 14 & Micrargeria wightii Benth. & Wild & Kodaikanal \\
\hline 15 & Calceolaria mexicana Benth. & Cultivated & Kodaikanal \\
\hline 16 & Antirrhinum majus $\mathrm{L}$. & Cultivated & Kodaikanal \\
\hline 17 & Digitalis purpurea $\mathrm{L}$. & Cultivated & Kodaikanal \\
\hline 18 & Angelonia grandiflora C. Morr. & Cultivated & Annamalaianagar \\
\hline 19 & Russelia juncea Zucc. & Cultivated & Annamalainagar \\
\hline 20 & Striga lutea Lour. & Wild & Annamalainagar \\
\hline 21 & S. densiflora Benth. & Wild & Annamalainagar \\
\hline
\end{tabular}


at $4^{\circ} \mathrm{C}$ for 3 hours. Then, after a thorough wash, they were fixed in $1: 3$ acetic ethanol for 3 hours and squashed following the schedule of iron alum haematoxylin squash technique described by Marimuthu and Subramaniam (1960). From the diagram drawn with camera lucida at stage level, the chromosome measurements pertaining to short/long arms were made with a standardized scale improvised for the purpose, the details of which are presented in Table 3. For the assessment of the morphology of the chromosomes, twelve metaphase plates in each species were studied critically for the sake of confirmation.
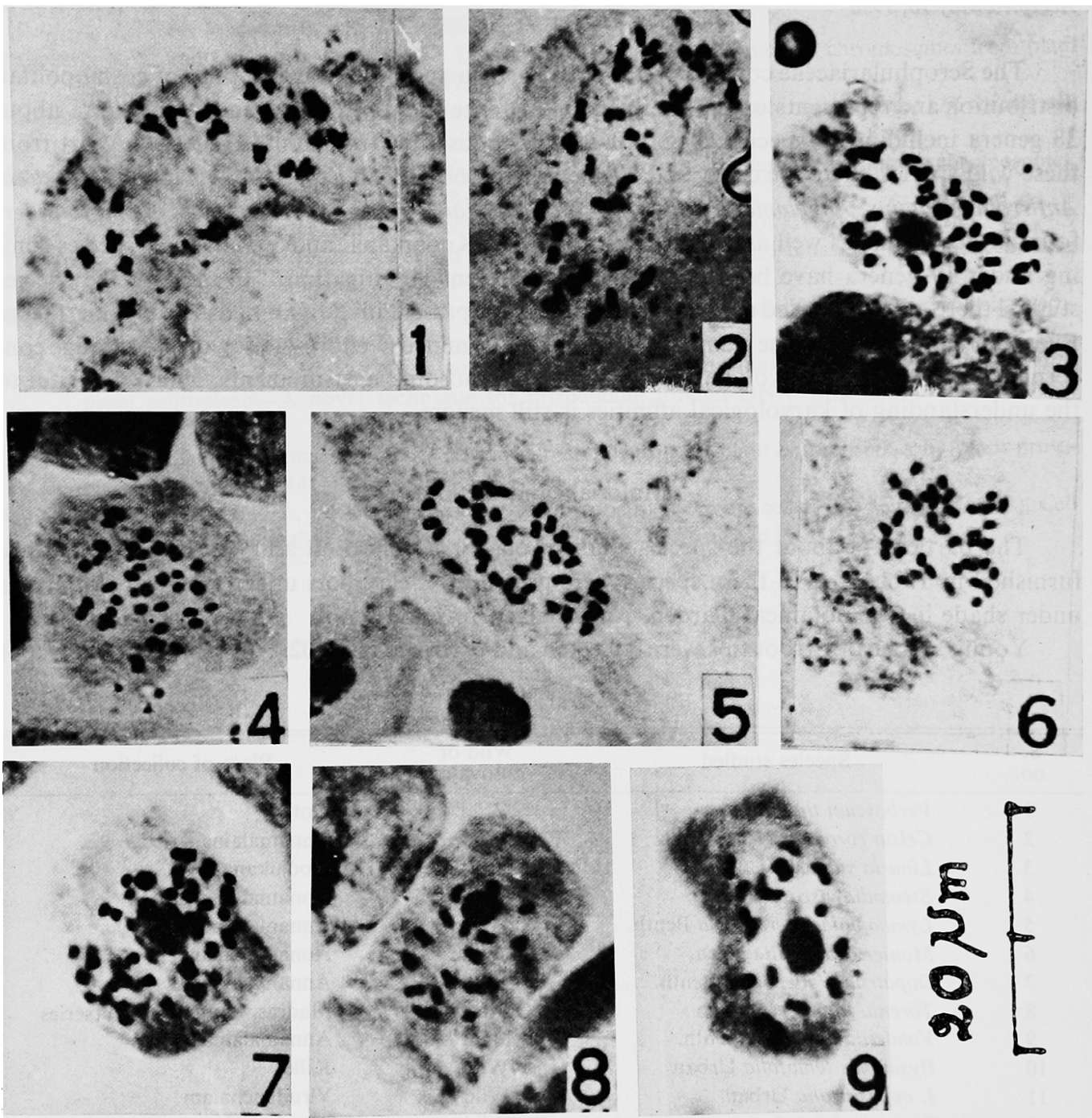

Figs. 1-9. 1, Celsia coromandeliana, metaphase, $2 \mathrm{n}=26$ chromosomes. 2, Stemodia viscosa, $2 \mathrm{n}=32$ chromosomes. 3, Stemodia viscosa, $2 \mathrm{n}=42$ chromosomes. 4, Vandellia crustacea, metaphase, $2 \mathrm{n}=42$ chromosomes. 5 and 6 , Scoparia dulcis, $2 \mathrm{n}=40$ chromosomes. 7, Digitalis purpurea, prometaphase with 48 chromosomes. 8, Angelonia grandiflora, prometaphase with 20 chromosomes. 8, Russelia juncea, prometaphase with 20 chromosomes.

\section{Observations}

The particulars about the present reports of somatic and meiotic chromosome numbers, previous reports of somatic chromosome numbers, authors and years are furnished in Table 2. 
In Verbascum thapsus, the somatic chromosome number is $2 n=34$. The previous reports show $2 n=34$ and 36 chromosomes in this species (Table 2). The present study shows the rare occurrences of 48 and 128 somatic chromosomes as well.

In Celsia coromandeliana, there are $2 \mathrm{n}=80$ chromosomes and this is confirmed by the earlier observation of Malik and Sobti, Singh (1961). Besides, there are rare occurrences of aneuploid cells with 26,36 and 72 chromosomes.

Table 2. Particulars about the species studied, somatic and meiotic chromosome numbers, previous reports of chromosome numbers, authors and years

\begin{tabular}{|c|c|c|c|c|c|}
\hline $\begin{array}{c}\text { S. } \\
\text { no. }\end{array}$ & Species studied & $\begin{array}{l}\text { Somatic } \\
\text { chromo- } \\
\text { some } \\
\text { numbers }\end{array}$ & $\begin{array}{l}\text { Meiotic } \\
\text { chromo- } \\
\text { some } \\
\text { numbers }\end{array}$ & \multicolumn{2}{|r|}{$\begin{array}{l}\text { Previous reports of somatic chromosome } \\
\text { numbers, authors and years }\end{array}$} \\
\hline 1 & Verbascum thapsus & 34 & 17 & \multicolumn{2}{|c|}{ 34, 36 Hakanson 1926} \\
\hline & & & & 36 & $\begin{array}{l}\text { Tischler 1934, Packer 1964, Heiser, } \\
\text { Whitaker 1948, Mulligan 1961a. }\end{array}$ \\
\hline 2 & Celsia coromandeliana & 80 & 40 & 80 & Malik 1960b, Sobti, Singh 1961. \\
\hline 3 & Linaria vulgaris & 12 & - & 12 & $\begin{array}{l}\text { Heitz 1926, 1927b, Lawrence } 1930 \text {; } \\
\text { East 1933, Tishcler 1934, Tandon, } \\
\text { Bali } 1958 .\end{array}$ \\
\hline 4 & Stemodia viscosa & 28 & 14 & \multirow[t]{3}{*}{42} & Raghavan, Srinivasan 1940b. \\
\hline 5 & Lymnophila heterophylla & $34^{*}$ & $17^{*}$ & & - \\
\hline 6 & Moniera cuneifolia & 80 & 40 & & - \\
\hline 7 & Dopatrium lobelioides & 14 & 7 & 14 & Raghavan, Srinivasan 1940b (D. 1955) \\
\hline 8 & Torenia fournieri & 18 & 9 & 18 & $\begin{array}{l}\text { Simon, Lowig 1930, Sugiura 1931, } \\
\text { 1936b, Straub 1939, Tandon, Bhutani } \\
\text { 1964. }\end{array}$ \\
\hline 9 & Vandellia crustacea & 42 & 21 & \multirow[t]{3}{*}{42} & Raghavan, Srinivasan 1940b. \\
\hline 10 & Ilysanthes tenuifolia & $16^{*}$ & $8^{*}$ & & - \\
\hline 11 & I. oppositifolia & $18^{*}$ & - & & - \\
\hline 12 & Scoparia dulcis & 40 & 20 & \multirow[t]{3}{*}{40} & $\begin{array}{l}\text { Lewis et al. } 1962 \text {. } \\
\text { Raghavan and Srinivasan } 1940 \mathrm{~b} .\end{array}$ \\
\hline 13 & Micrargeria wightii & - & $16^{*}$ & & - \\
\hline 14 & Sopubia trifida & $36^{*}$ & - & & - \\
\hline 15 & Calceolaria mexicana & 60 & 30 & 60 & Sugiura 1928a, Srinath 1940 (D. 1955). \\
\hline 16 & Antirrhinum majus & 24 & 12 & 16 & $\begin{array}{l}\text { Winge } 1925, \text { Heitz 1927a, b; Straub, } \\
\text { 1939, Stubbe } 1966 .\end{array}$ \\
\hline & & & & & $\begin{array}{l}\text { Bamford, Winkler } 1941 . \\
\text { Rajhathy 1960a. }\end{array}$ \\
\hline 17 & Digitalis purpurea & 48 & 24 & $\begin{array}{l}48 \\
56\end{array}$ & $\begin{array}{l}\text { Hassae-Bessel 1916, } 1921 . \\
\text { Buxton, Newton 1928, Michaelis 1931, } \\
\text { Regnart 1935, Sakai 1935a, Love and } \\
\text { Love 1956b, Carpio 1957, } 1963 .\end{array}$ \\
\hline 18 & Angelonia grandiflora & 20 & 10 & 20 & Raghavan, Srinivasan 1940b. \\
\hline 19 & Russelia juncea & 20 & 10 & 20 & $\begin{array}{l}\text { Pal 1961, Takag 1938, Raghavan and } \\
\text { Srinivasan 1940b. }\end{array}$ \\
\hline 20 & Striga lutea & - & 20 & 40 & Kumar, Abraham 1941. \\
\hline 21 & S. densiflora & - & 20 & 40 & Kumar, Abraham 1941. \\
\hline
\end{tabular}

* First record of somatic and meiotic chromosome numbers.

In Linaria vulgaris, there are $2 \mathrm{n}=12$ chromosomes and this is confirmed by the earlier reports of Heitz (1926), Lawrence (1930), etc. (vide, Fedorov 1974).

In Stemodia viscosa, there are $2 \mathrm{n}=28$ chromosomes and this count differs from the earlier report of Raghavan and Srinivasan $(1940 \mathrm{~b}, 1942)$ who reported $2 \mathrm{n}=42$ chromosomes in this species. There are also rarely aneuploid cells with $2 n=32$ and 42 chromosomes in this species, 
as evidenced by the present investigation.

In Dopatrium lobelioides, there are $2 \mathrm{n}=14$ chromosomes and this is confirmed by the previous reports of Raghavan and Srinivasan (1940b).

In Torenia fournieri, there are $2 \mathrm{n}=18$ chromosomes and also rarely 36 chromosomes. The

\section{IDIOGRAM}

Verbascum thapsus

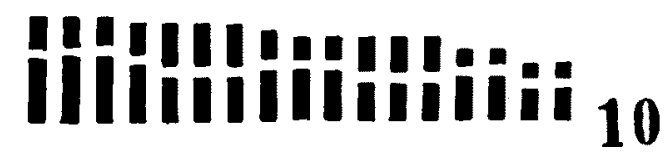

Celsia coromandelina

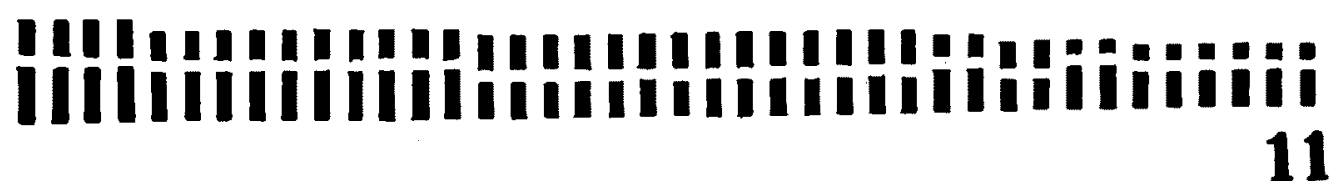

Linaria vulgaris

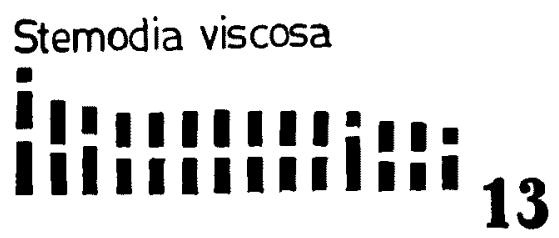

Lymnophila heterophylla

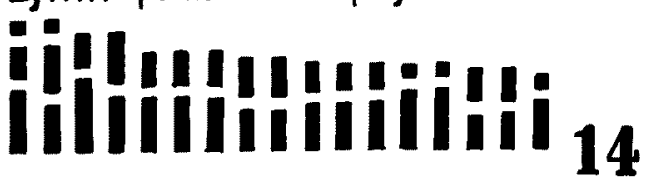

Monira cuneifolia
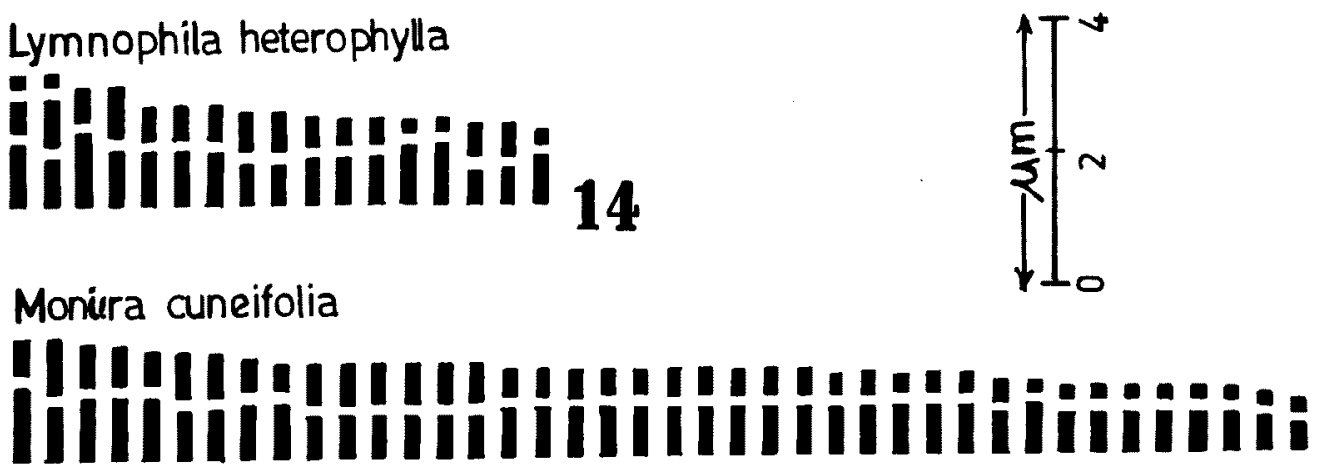

Dopatrium lobelioides

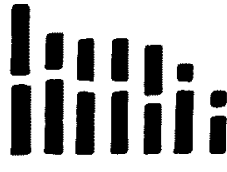

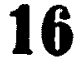

Torenia fournieri

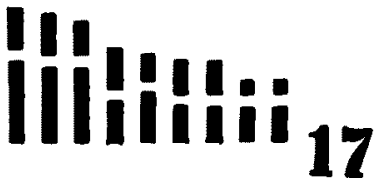

Figs. 10-17. Idiograms of the various species mitotically studied.

earlier reports also show $2 n=18$ chromosomes in this species (Table 2).

In Vandellia crustacea, there are $2 \mathrm{n}=42$ chromosomes. This number is confirmed by the earlier reports (Table 2). Besides, there are rarely cells in this species, having $2 n=22$ and 28 chromosomes. 
In Scoparia dulcis, there are $2 \mathrm{n}=40$ chromosomes. According to Lewis et al. (1962), there are $2 \mathrm{n}=20$ chromosomes in this species, but according to Raghavan and Srinivasan (1940b) there are $2 n=40$ chromosomes. Therefore, there may be different euploid populations available in this species.

In Calceolaria mexicana, the present study shows $2 n=60$ chromosomes and this number is

\section{IDIOGRAM}

Vandellia crustacea

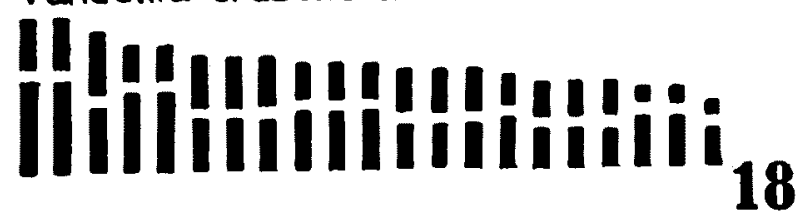

Ilysanthes tenuifolia

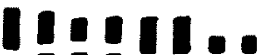

IIIIHii $_{19}$

Ilysanthes oppositifolia

Scoparia dulcis

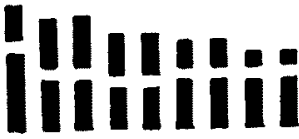

20

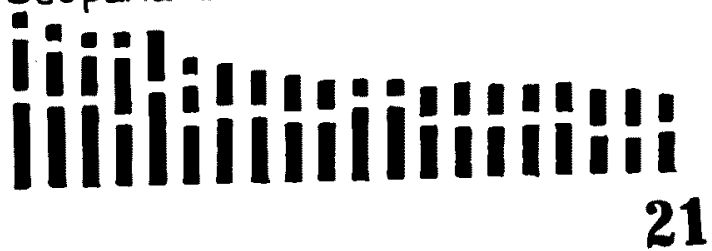

Sopubia trifida

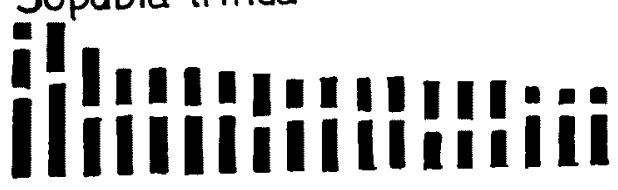

Calceolaria mexicana
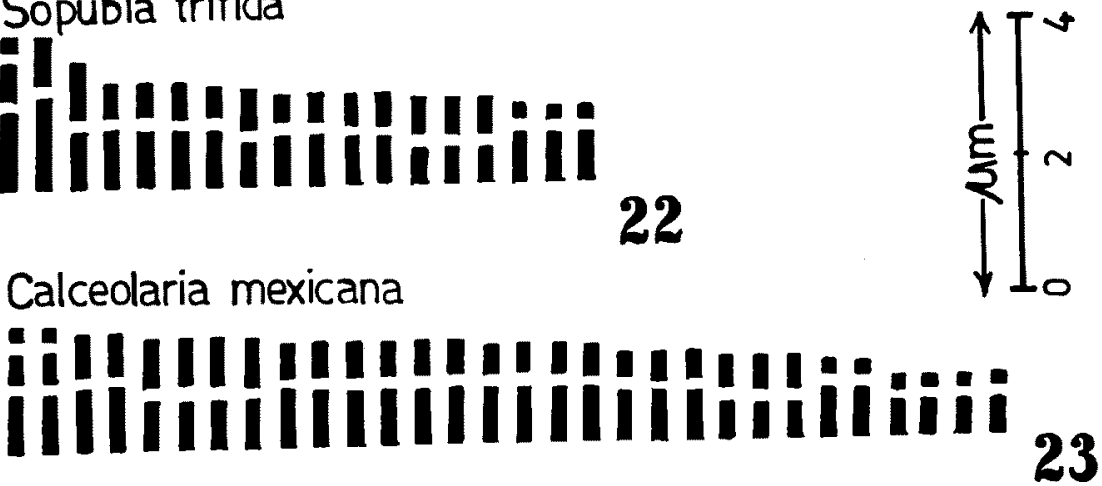

Antirrhinum majus

Digitalis purpurea

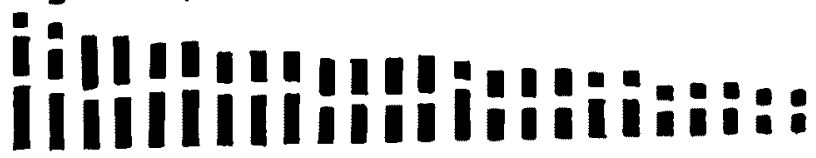
24

Angelonia grandiflora

22
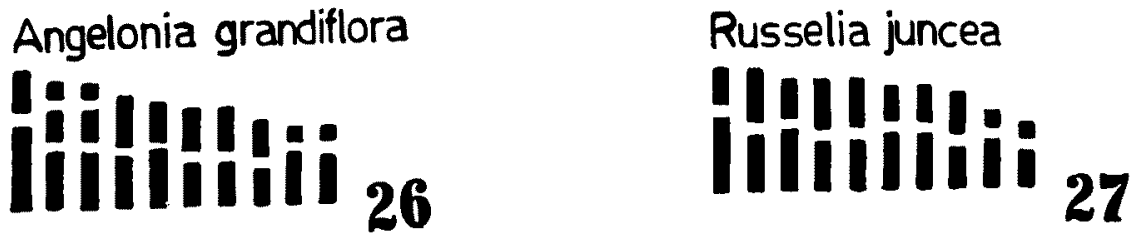

Figs. 18-27. Idiograms of the various species mitotically studied. 
confirmed by the earlier reports (Table 2 ).

In Antirrhinum majus, there are $2 \mathrm{n}=24$ chromosomes and in Digitalis purpurea $2 \mathrm{n}=48$ chromosomes. The earlier reports show $2 n=16$ and 32 chromosomes in the former species and $2 \mathrm{n}=48$ and 56 chromosomes in the latter.

In Angelonia grandiflora and Russelia juncea, there are $2 n=20$ chromosomes and in Striga lutea and $S$. densiflora, $2 \mathrm{n}=40$ chromosomes and the counts in these 4 species have been confirmed by the earlier observations (Table 2).

In Ilysanthes tenuifolia, I. oppositifolia, Sopulia trifida, Lymnophila heterophylla, Moniera cuneifoia and Micrargeria wightii first record of chromosome numbers have been made.

28

HISTOGRAM

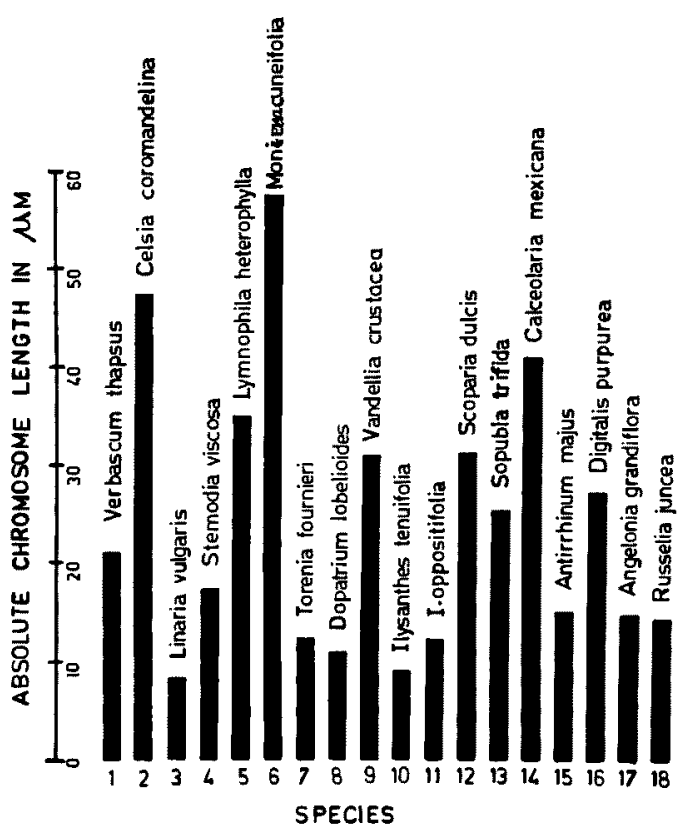

Fig. 28. Histogram showing the absolute chromosome lengths of the species studied.

The chromosomes of most of the taxa of Scrophulariaceae are rather smaller. The size of them ranges from 0.6 to $2.5 \mu \mathrm{m}$. Based on the length, the chromosomes have been grouped into shorter, short, medium and long sized chromosomes. Under each of these groups, the following categories of chromosomes have been recognized.

Long $(2.0 \mu \mathrm{m}$ to $2.5 \mu \mathrm{m})$

Type $A$ : Chromosome with medium primary and subterminal secondary centromeres.

Type B: Chromosome with submedian primary and subterminal secondary centromeres.

Type C: Chromosome with submedian centromere.

Type D: Chromosome with median centromere.

Medium $(1.5 \mu \mathrm{m}$ to $1.9 \mu \mathrm{m})$

Type E: Chromosome with submedian primary and subterminal secondary centromeres.

Type F: Chromosome with submedian centromere.

Figs. $29-104.29$ to $34=$ Verbascum thapsus; $29=$ prometaphase with 17 bivalents; $30=$ tripolar anaphase; 31 to $33=$ tetrads with 2 or 3 sterile pollens; $34=$ metaphase II; 35 to $37=$ Celsia coromandeliana; $35=$ metaphase with 49 bivalents; 36 to $41=$ combinations of univelents, trivalents, quadrivalents and multivalents along with bivalents; $42=I$ anaphasic bridge; $43=$ tripolar anaphase; $44=I$ anaphasic laggard; $45=$ metaphase II; $46=I I$ anaphasic bridges and laggards; $47=$ polyads; 48 to $51=$ Stemodia viscoa; $48=$ metaphase with 14 bivalents; $49=$ prometaphase; 50 and $51=$ combinations of quadrivalents and multivalents with bivalents; 52 to $49=$ Lymnophila heterophylla; $52=$ metaphase with 17 bivalents; 53 to $56=$ combinations of univalents, trivalents quadrivalents and multivalents along with bivalents; $57=$ tripolar anaphase; $58=$ opposite orientation of II anaphase; $59=I$ anaphasic laggards; 60 to $67=$ Moniera cuneifolia; 60 and $61=$ metaphase and prometaphase with 40 bivalents; $62=$ tripolar anaphase; $63=I$ anaphasic laggards; 64 to $66=I$ anaphasic bridges; $67=$ multipolar anaphase; 68 to $78=$ Dopatrium lobelioides; $68=$ metaphase with 7 bivalents; 69 to $71=$ combinations of univalents, trivalents quadrivalents; 72 and $73=$ metaphase II; $74=\mathrm{I}$ anaphasic laggard; $75=$ tripolar anaphase; $76=\mathrm{II}$ anaphasic laggard; 77 and $78=$ tetrads with 1 and 2 sterile pollens respectively; 79 to $88=$ Torenia fournieri; 79 and $80=$ prometaphase and metaphae with 9 bivalents; 81 to $83=$ combinations of multivalents, quadrivalents, trivalents and univalents with bivalents; $84=$ tripolar anaphase; $85=I$ anaphasic 


\section{MEIOSIS}

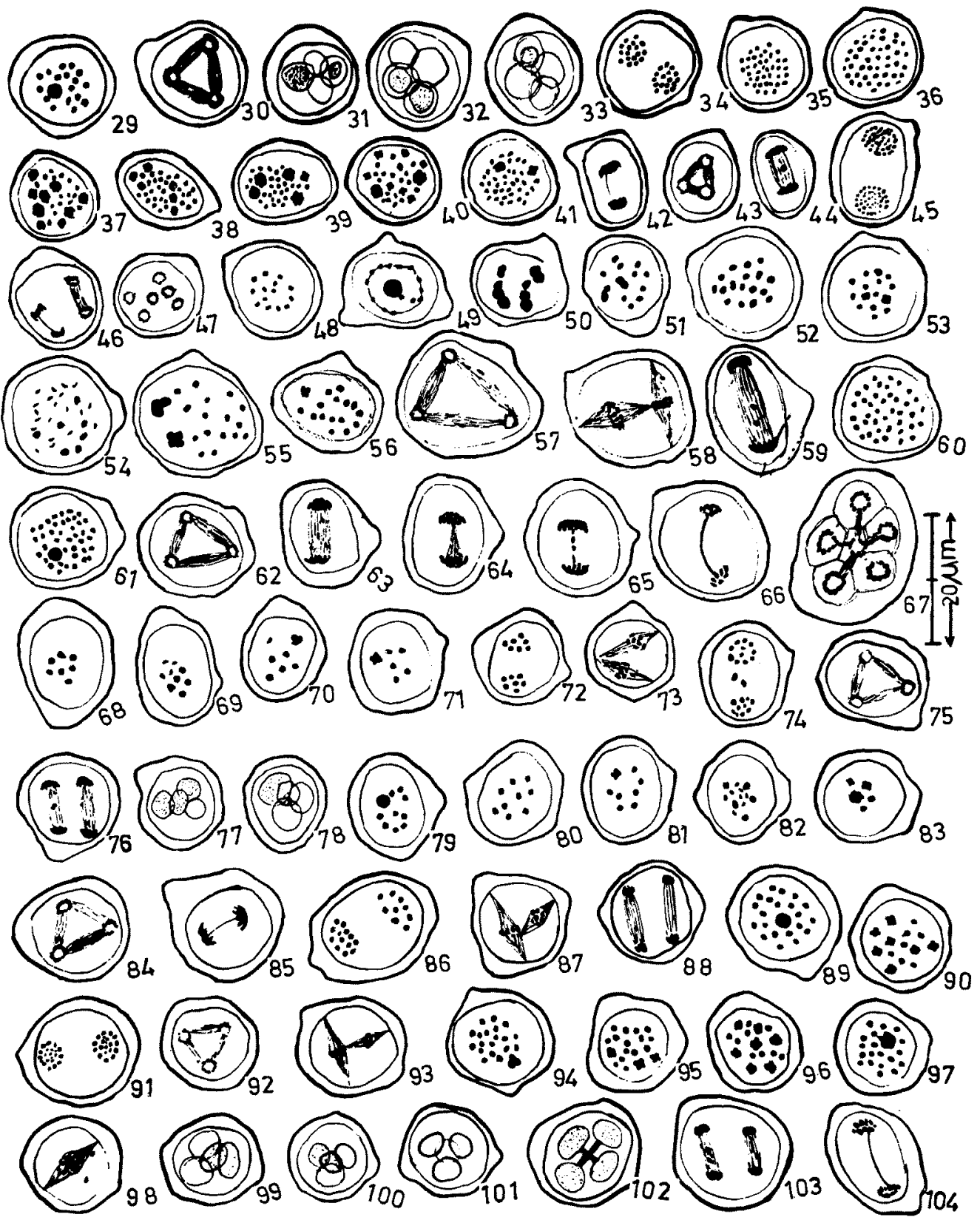

bridge; $86=$ metaphase II; $87=$ opposite orientation of anaphase II; $88=$ unequal anaphase II; 89 to $104=$ Vandellia crustacea $; 89=$ prometaphase with 21 bivalents; $90=$ cpmbinations of quadrivalents and bivalents; $91=$ metaphase II with larger and smaller chromosomes; 92 and 94 to $97=$ tripolar anaphases; $93=$ opposite orientation of metaphase II; $98=$ precocious movements of chromosomes at metaphase I; 99 to $101=$ tetrads with 2 and 4 sterile pollens. $102=$ chromatin connections among the pollen grains of tetrads; $103=$ II anaphasic laggard; $104=I$ anaphasic bridge. 
Type G: Chromosome with median centromere.

Type $H$ : Short $(1.0 \mu \mathrm{m}$ to $1.4 \mu \mathrm{m}) \quad$ Chromosome with submedian centromere.

Type 1: Chromosome with median centromere.

Type $J$ : Chromosome with subterminal centromere.

Type K: Shorter $(0.6 \mu \mathrm{m}$ to $0.9 \mu \mathrm{m})$ Chromosome with median centromere.

Type L: Chromosome with subterminal centromere.

The total number of secondary constricted chromosomes has been found to vary from species to species. The details of chromosome measurements are given in Table 3 . In this table, the particulars about the karyotype analyses of the species and the descriptions of the various columns are as follows:

1. Chromosome number (2n)

2. Size range in millimicrons

3. Number of chromosomes with secondary constrictions

4. Number of chromsomes with submedian constrictions

5. Number of chromosomes with median constrictions

Table 3. Summarised karyomorphological features of the taxa investigated here

\begin{tabular}{|c|c|c|c|c|c|c|c|c|}
\hline Taxa & 1 & 2 & 3 & 4 & 5 & 6 & 7 & 8 \\
\hline Verbascum thapsus & 34 & 0.8 to 1.5 & 1 & 14 & 12 & 8 & 42.0 & 1.66 \\
\hline Celsia coromandeliana & 80 & 0.9 to 1.5 & - & 32 & 32 & 16 & 94.8 & 1.186 \\
\hline Linaria vulgaris & 12 & 1.2 to 2.3 & - & 4 & 6 & 2 & 17.6 & 1.466 \\
\hline Stemodia viscosa & 28 & 0.9 to 1.9 & 2 & 2 & 20 & 4 & 34.2 & 1.22 \\
\hline Limnophila heterophylla & 34 & 1.1 to 2.0 & 4 & 14 & 10 & 6 & 49.8 & 1.46 \\
\hline Moniera cuneifolia & 80 & 0.8 to 1.8 & - & 34 & 28 & 18 & 115.6 & 1.45 \\
\hline Dopatrium lobelioides & 14 & 0.9 to 2.2 & - & 6 & 4 & 4 & 22.4 & 1.60 \\
\hline Torenia fournieri & 18 & 0.9 to 2.0 & - & 8 & 6 & 4 & 25.2 & 1.40 \\
\hline Vandellia crustacea & 42 & 0.9 to 2.2 & - & 16 & 20 & 6 & 63.0 & 1.50 \\
\hline llysanthes tenuifolia & 16 & 0.9 to 1.4 & - & 6 & 6 & 4 & 18.0 & 1.16 \\
\hline I. oppositifolia & 18 & 1.1 to 1.8 & - & 6 & 8 & 4 & 25.2 & 1.40 \\
\hline Scoparia dulcis & 40 & 1.1 to 2.5 & 10 & 22 & 4 & 4 & 63.4 & 1.59 \\
\hline Sopubia trifida & 36 & 1.1 to 2.2 & 2 & 18 & 10 & 6 & 52.2 & 1.42 \\
\hline Calceolaria mexicana & 60 & 0.9 to 1.8 & 4 & 22 & 22 & 12 & 82.6 & 1.38 \\
\hline Antirrhinum majus & 24 & 0.9 to 1.6 & - & 8 & 12 & 3 & 30.2 & 1.26 \\
\hline Digitalis purpurea & 48 & 0.6 to 2.0 & 4 & 10 & 18 & 16 & 55.8 & 1.16 \\
\hline Angelonia grandiflora & 20 & 1.1 to 2.0 & 4 & 4 & 8 & 4 & 29.8 & 1.49 \\
\hline Russelia juncea & 20 & 0.9 to 1.8 & - & 8 & 8 & 4 & 29.6 & 1.48 \\
\hline
\end{tabular}

Figs. 105-178. $105=109=$ Ilysanthes tenuifolia; $105=$ prometaphase with 8 bivalents; $106=$ quadrivalents and bivalents at metaphase I; $107=$ metaphase II with 8 chromosomes at each pole; $108=$ tripolar anaphase; $109=I$ anaphasic birdge; 110 to $118=$ Scoparia dulcis $; 110=I$ metaphase with 20 bivalents; 111 to $113=$ combinations of mutivalents, quadrivalents and bivalents; $114=$ tripolar anaphase; 115 to $117=$ tetrads with 2 and 4 sterile pollens; $118=$ chrometin connections among the 4 pollens of the tetrads; 119 to $128=$ Micrargeria wightii; $119=$ metaphase I with 20 bivalents; 120 to $124=$ combinations of multivalents, quadrivalents, trivalents and univalents with bivalents; $125=$ metaphase II; 126=tripolar anaphase; $127=\mathrm{I}$ anaphasic laggard; $128=$ polyads; 129 to $137=$ Calceolaria mexicana; $129=$ prometaphase with 30 bivalents; $130=$ prometaphase with 15 bivalents; $131=$ metaphasic nucleus; $132=$ tripolar anaphase. $133=$ tetrad with one sterile pollen; $134=$ tetrad with 4 fertile pollens; $135=$ precocious movements of chromosomes at metaphase I; 136 and $137=\mathrm{I}$ anaphasic bridges; 138 to $145=$ Antirrhinum majus; 138 and $139=$ prometaphase and metaphase with 12 bivalents; 140 and $141=$ combinations of quadrivalents, multivalents and bivalents; $142=$ metaphase II; 143 and $144=$ polyads; $145=I$ anaphasic bridge; 146 to $153=$ Digitalis purpurea; 146 and $147=$ prometaphase and metaphase with 24 bivalents; 148 to $150=$ combinations of quadrivalents, multivalents, univalents and bivalents; $151=$ metaphasic nucleus; $152=$ tripolar anaphase; $153=$ multipolar anaphase; 154 to $146=$ Angelonia grandiflora; 154 and $155=$ prometaphase and metaphase with 10 bivalents; 156 and $157=$ combinations of multivalents, quadrivalents, trivalents, univalents and bivalents; $158=I$ anaphasic 
MEIOSIS

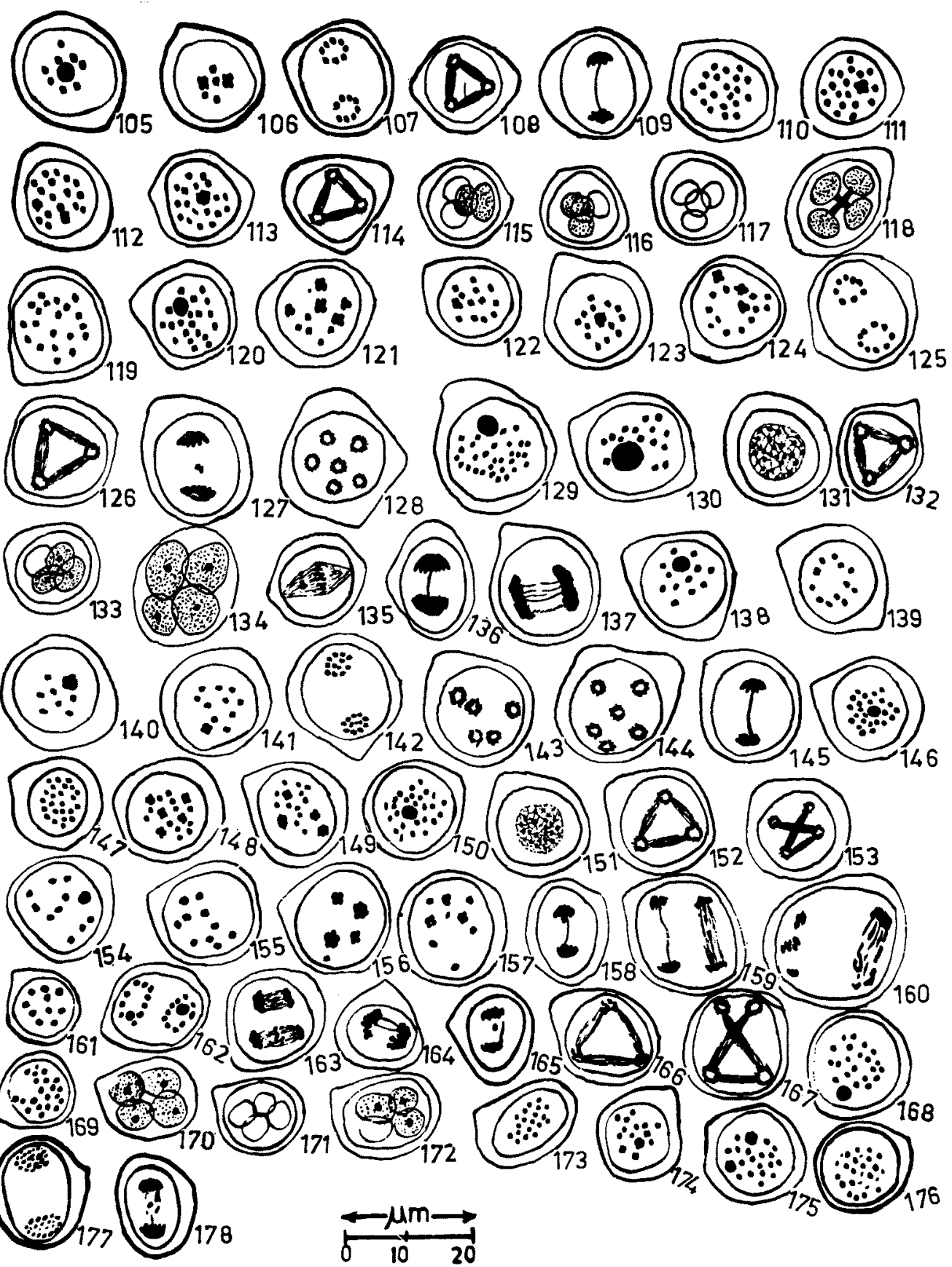

bridge; $159=\mathrm{II}$ anaphasic bridge; $160=\mathrm{II}$ anaphasic laggards; 161 to $167=$ Russelia juncea $; 161=$ metaphase I with 10 bivalents; $162=$ prometaphase II with 10 chromosomes at each pole; $163=$ II anaphasic laggards; 164 and $165=\mathrm{I}$ anaphasic bridges and laggards; $166=$ tripolar anaphase; $167=$ multipolar anaphase; 168 to $172=$ Striga lutea; 168 and $169=$ prometaphase and metaphase with 20 bivalents; 170 and $171=$ tetrads with 4 sterile pollens; $172=$ tetrads with 2 sterile pollens; 173 to $178=$ Striga densifora; $173=$ metaphase with 20 bivalents; 174 to $176=$ combinations of quadrivalents, multivalents, univalents and bivalents; $177=$ II metaphase with smaller and larger chromosomes; $178=I$ anaphasic laggards. 
6. Number of chromosomes with subterminal constrictions

7. Absolute chromosome length in millimicrons

8. Average chromosome length in millimicrons

2 to 4 and rarely 10 secondary constricted chromosomes were observed in 7 out of 18 species examined. A comparison of the total chromatin contents in different species shows a range from $17.6 \mu \mathrm{m}$ to $115.6 \mu \mathrm{m}$, the lowest being in Linaria vulgaris and the highest being in Moniera cuneifolia. This indicates considerable variation in total chromatin content. However, it should be added that the possibility of a part of this variation being due to differences in the degree of condensation of the chromosomes cannot be ruled out. More emphasis, therefore, will have to be laid on the degree of asymmetry rather than on total chromatin content. The mitotic plates for some of the species studied are presented in Figs. 1 to 9 and their idiograms are presented in Figs. 10 to 27 and the histogram showing absolute chromosome lengths of the 18 species studied mitotically are presented in Fig. 28. The figures illustrate the differences in the karyotypes of different species.

Meiotic study has been made in Verbascum thapsus, Celsia coromandeliana, Stemodia viscosa, Lymnophila heterophylla, Moniera cuneifolia, Dopatrium lobelioides, Vandelia crustacea, Ilysanthes tenuifolia, Scoparia dulcis, Micrargeria wightii, Calceolaria mexicana, Antirrhinum majus, Digitalis purpurea, Angelonia grandiflora, Russelia juncea, Striga lutea and in all these species, the haploid number is in confirmation with diploid numbers.

\section{Discussion}

Cytological studies have been made in 21 taxa of South Indian Scrophulariaceae, in which first record of chromosome number has been made in Lymnophila heterophylla, Ilysanthes tenuifolia, I. oppositifolia, Micrargeria wightii and Sopubia trifida.

In the present study when the karyotype of 18 taxa were examined, it was obvious that karyotype asymmetry was of a high order. From the works of Löve and Löve (1942) on boreal plants, Babcock (1947) in Crepis, Satô (1942) in Liliaceae and Stebbins, Jenkins and Walters (1953) in Cichorieae of Asteraceae, and Sharma and Sarkar (1950) in plams, it is clear that chromosomes of uniform size with symmetrical karyotypes are likely to be found in less derived plants than those of unequal size with asymmetrical karyotypes. Besides, the 'SC' chromosomes with two constrictions have been observed in 7 out of 18 species mitotically studied. We may assume that the absence of two more constricted chromosomes in most of the taxa studied may be an indication of the advanced status of the family. The karyotype analyses of the taxa of Myrtaceae by Atchison (1947) support the same conclusion. The karyotype anayses of the various species studied show that each and every species has a distinct karyotype. Therefore, it may be assumed that karyotype alteration plays important role in speciation.

The Scrophulariaceae shows a wide range of basic numbers from 6 to 84 (Fedorov 1974). The commonest basic number in the family is $\mathrm{n}=8$ and it is assumed to be the original basic number of the family and that $\mathrm{n}=10,11,12,13,14$ etc. derived by polyploidy. Evolution of an aneuploid series $(n=6,7,8,9,10,11,12,13,14,17,18,20,23,24,28,30,32,50,60$ etc. $)$ from the original number $\mathrm{n}=8$, followed by polyploidy might have given rise to the wide range of basic numbers now observed in the family.

The formation of an aneuploid series prior to polyploidy is indicated by Ilysanthes tenuifolia $(2 \mathrm{n}=16)$, I. oppositifolia $(2 \mathrm{n}=18)$, Torenia fournieri $(2 \mathrm{n}=18)$, Angelonia grandiflora $(2 \mathrm{n}=20)$, Russelia juncea $(2 \mathrm{n}=20)$, Antirrhinum majus $(2 \mathrm{n}=24)$ and Vandellia crustacea $(2 \mathrm{n}=28)$, as evidenced by the present investigation (Table 4). Basic numbers 17 to 30 and above might have been arisen by diphasic amphidiploidy, by combination of any two basic numbers by natural hybridizations and or by gain or loss of chromosomes following polyploidy. Examples for 
this type of evolution are Verbascum thapsus $(2 \mathrm{n}=34)$, Lymnophila heterophylla $(2 \mathrm{n}=34)$, Celsia coromandeliana $(2 \mathrm{n}=36)$, Moniera cuneifolia $(2 \mathrm{n}=36)$, Sopubia trifida $(2 \mathrm{n}=36)$, Scoparia dulcis $(2 \mathrm{n}=40)$, Striga lutea $(2 \mathrm{n}=40), S$. densiflora $(2 \mathrm{n}=40)$, Digitalis purpurea $(2 \mathrm{n}=48)$ and Calceolaria mexicana $(2 n=60)$, as evidenced by the present investigation. It is concluded that aneuploid and diphasic amphidiploidy together with structural alterations of chromosomes play important role in speciation.

Meiotic studies have been made in 18 species of 21 taxa included in the present investigation and the haploid chromosome numbers of the species were found to be in conformity with the diploid numbers.

Anaphasic laggards and bridges have been noticed in Celsia coromandeliana, Moniera cuneifolia, Dopatrium lobelioides, Torenia fournieri, Vandellia crustacea, Scoparia dulcis, Micrargeira wightii, Calceolaria mexicana, Antirrhinum majus, Angelonia grandiflora, Russelia juncea and Striga densiflora. It is an established fact that the bridges and fragments at anaphase I and

Table 4. Chromosome types

\begin{tabular}{|c|c|c|c|c|c|c|c|c|c|c|c|c|}
\hline \multirow{2}{*}{ Taxa } & \multicolumn{4}{|c|}{ Long } & \multicolumn{3}{|c|}{ Medium } & \multicolumn{3}{|c|}{ Short } & \multicolumn{2}{|c|}{ Shorter } \\
\hline & A & B & $\mathrm{C}$ & D & E & $F$ & G & $\mathbf{H}$ & $I$ & $\mathbf{J}$ & $\mathbf{K}$ & $\mathrm{L}$ \\
\hline Verbascum thapsus & - & - & - & - & - & 6 & - & 8 & 12 & 4 & - & 4 \\
\hline Celsia coromandeliana & - & - & - & - & - & 8 & - & 24 & 32 & 4 & - & 12 \\
\hline Linaria vulgaris & - & - & - & 2 & - & 2 & - & - & 6 & 2 & - & - \\
\hline Stemodia viscosa & - & - & - & - & 2 & - & - & 2 & 20 & 2 & - & 2 \\
\hline $\begin{array}{l}\text { Lymnophila } \\
\text { heterophylla }\end{array}$ & 2 & 2 & - & - & 8 & - & 2 & - & 8 & 6 & - & - \\
\hline Moniera cuneifolia & - & - & - & - & - & 10 & 6 & 24 & 22 & 12 & - & 4 \\
\hline Dopatrium lobelioides & - & - & - & 2 & - & 6 & 2 & - & - & 2 & - & 2 \\
\hline Torenia fournieri & - & - & 2 & - & - & 4 & - & 2 & 6 & - & - & 4 \\
\hline Vandellia crustacea & - & - & 4 & 2 & - & 10 & 6 & 2 & 12 & 4 & - & 2 \\
\hline Ilysanthes tenuifolia & - & - & - & - & - & - & - & 6 & 6 & - & - & 4 \\
\hline I. oppositifolia & & & & & & 2 & 4 & 4 & 4 & 4 & - & - \\
\hline Scoparia dulcis & 6 & 2 & 2 & - & 2 & 6 & - & 14 & 4 & 4 & - & - \\
\hline Sopubia trifida & 2 & - & 2 & - & - & 2 & 2 & 10 & 8 & 6 & - & - \\
\hline Calceolaria mexicana & - & - & - & - & 2 & 16 & 8 & 6 & 14 & 4 & - & 8 \\
\hline Antirrhinum majus & - & - & - & - & - & 2 & 2 & 6 & 10 & - & - & 4 \\
\hline Digitalis purpurea & 2 & - & - & - & 2 & 4 & 4 & 6 & 14 & 2 & - & 14 \\
\hline Angelonia grandiflora & - & - & 2 & - & 4 & 2 & 2 & - & 6 & 4 & - & 一 \\
\hline Russelia juncea & - & - & - & - & - & 8 & 6 & - & 2 & 2 & - & 2 \\
\hline
\end{tabular}

II are indicative of inversion heterozygosity (Upcott 1937). The frequency of bridge formation in any species depends on three factors namely, chiasma frequency, number of inversions and size of inversions. Out of 18 species meiotically studied here, bridges and laggards have been observed in 12 species. This shows that inversion heterozygosity has also played important role in speciation. The inversion heterozygosity is known to cause univalency and the univalents formed are lagged behind as anaphasic laggards. In most of the species meiotically studied, multivalents and quadrivalents occur along with bivalents during metaphase. The formations of these may be attributed to polyploidy or structural alterations in the chromosomes. The species studied are aneuploids and therefore, these multivalents and quadrivalents are due to aneuploid nature of the species. The same may be responsible of the presence of tripolar anaphases observed in Verbascum thapsus, Celsia coromandeliana, Lymnophila heterophylla, Moniera cuneifolia, Dopatrium lobelioides, Torenia fournieri, Vandelia crustacea, Ilysanthes tenuifolia, Scoparia dulcis, Micrargeria wightii, Calceolaria mexicana, Digitalis purpurea and Russelia juncea. 


\section{Summary}

The chromosome number of 21 species belonging to 17 genera of Scrophulariaceae from South India has been studied, of which first record of chromosome has been made in Lymnophila heterophylla, Moniera cuneifolia, Ilysanthes tenuifolia, I. oppositifolia, Micrargeria wightii and Sopulia trifida. Chromosome numbers determined in the present study range from $2 n=12$ to $20=80$.

Chromsome numbers determined in the present study and those reported previously in the family (Fedorov 1974) reveal the presence of a continuous series of basic number between $\mathrm{n}=6$ to 84 . The commonest basic number in the famly is $n=8$ and it is assumed to be the original basic number of the family. It appears that aneuploid changes of chromosome numbers produced the basic numbers of $\mathrm{n}=6,7,8,9,10,11,12,13$ and 14 in the early evolution of the family, after which polyploid and dibasic amphidiploid gave rise to the higher basic numbers $(n=17$ to $n=84)$ now found in the family.

Karyotypes in the family also show differences in absolute chromosome size indicating changes in nuclear DNA in evolution. The meiotic chromosome number studied in 17 species is in confirmation with the mitotic chromosomes. The presence of mutivalents and quadrivalents along with bivalents and the presence of anaphasic laggards and bridges and triplar anaphases show evidences in support of the aneuploid and polyploid nature of the species.

\section{Acknowledgement}

The authors are thankful to Prof. Dr. R. Gaenesan, Head of the Department of Botany, Annamalai University and authorities of Annamalai University for their kind encouragement throughout the course of this investigation.

\section{References}

Atchinson, K. 1974. Chromosome numbers in Myrtaceae. Amer. J. Bot. 4: 159-164.

Babcock, E. B. 1974. The genus Crepis I and II. Univ. Calif. Publ. Bot. 21 and 22; 1030.

Bamford, R. and Winklert, F. B., 1941. A spontaneous tetraploid snapdragon. J. Heridity 32(8): 278.

Buxton, B. H. and Newton, W. C. F. 1928. Hybrids of Digitalis ambigua and Digitalis purpurea, their fertility and cytology. J. Genetics 19(3): 269-278.

Carpio, M.D. A. 1957. Estudios cariologicos en especies espanolas del genero Digitalis. Genetica. Iberica 9(3): $163-222$.

- 1963. Resultados obtenidos en los cruzamientos entre Digitalis purpurea L. Y. D. canariensis L. Agron Lusitama 25(4): 417-432.

East, E. M. 1933. Genetic observations on the genus Linaria. Genetics 18(4): 324-328.

Fedorov, A. N. A. 1974. Chromosome numbers of flowering plants. Acad. Sci. of the U.S.S.R.

Gamble, J. S. 1956. Flora of Presidency of Madras Vol. II. B.S.I. Publication, Calcutta.

Hakansson, A. 1926a. Zur Zytologie von Celsia und Verbascum. Acta. Univ. Lundensis (Lunds Univ. Arsskr), Avd. 2, 21, 10: 1-47.

Heiser, C. B., Whitaker, T. W. 1948. Chromosome number polypolidy and growth habit in California weeds. Amer. J. Bot. 35(3): 179-186.

Heitz, E. 1926. Der Nachweis der Chromosomen. Vergleichende Studien über ihre Zahl, Grosse und Form im Pflanzenreich I. Zeitschr. Bot. 18(11-12): 625-681.

- 1927a. Chromosomen und Gestalt bei Antirrhinum und verwandlen Gattungen. Planta 4(3): 392-410.

- 1927b. Über multiple und aberrante Chromosomen-Zahlen. Abhandl. Naturwiss. Vereins Hamburg 21(3-4): 47-57.

Kumar, L. S. S., Abaraham, A. 1941. Cytological studies in Indian parasitic plants. Proc. Indian. Acad. Sci., Sec. B. 14(6): 509-516.

Lawrence, W. J. C. 1930. Incompatibility in polyploids. Genetica. 12(1-2): 269-296.

Lewis, W. H., Stripling, H. L. and Ross, R. G. 1962. Chromosome numbers for some Angiosperms of the 
Southern United States and Mexico. Rhodora. 64(758): 147-161.

Löve, A. and Löve, D. 1942. Cytotaxonomical studies on boreal plants. Fysiograf. Selerkret Lund. Forhand. 12: $1-9$.

- and - 1956b. Cytotaxonomical conspectus of the Icelandic flora. Acta. Horti. Gothoburgensis. 20(4): $65-291$.

Malik 1969b. Chromosome number of some Dicotyledons. Sci. and Culture 25(7): 437 .

Marimuthu, K. M. and Subramaniam, M. K. 1960. A haematoxylin squash method for the root tips of Dolichos lablab L. Curr. Sci. $20: 482-483$.

Michaelis, P. 1931. Zur Kenntnis einiger Digitalis Bastarde. Biol. Zentralbl. 51(3): 124-134.

Mulligan, G. A. 1961. Chromosome numbers of Canadian Weeds III. Canadian. J. Bot. 39(5): 1057-1066.

Packer, J. C. 1964. Chromosome numbers and taxonomic notes on western. Canadian. J. Bot. 42(4): 473494.

Pal, N. 1961. Cytological studies on the genus Russelia. Caryologia 14(1): 141-150.

Raghavan, T.S., Srinivasan, V. K. 1940b. Studies in the Scrophulariaceae I. The cytology of Angelonia grandiflora. (Morr. and some Related genera). Cytologia 11(1-2): 37-54.

Regnart, H. C. 1935. Studies on hybrids in the genus Digitalis $\mathrm{I}$. The cytology of a sterile hybrid between Digitalis dubia and Digitalis purpurea. Genetica. 17(1-2): 145-153.

Sakai, K. 1935a. Studies on the chromosome number in alpine plants I. Jap. J. Genetics. 11(1): 68-73.

Sato, D. 1942. Karyotype alteration and phylogeny in Liliaceae and allied families. Jap. J. Bot. 12: 57-132.

Sharma, A. K. and Sarkar, S. K. 1956. Cytology of different species of palms and its bearing on the solution of the problems of phylogeny and separations. Genetica 28: 361-488.

Simon, S. V. and Lowing, E. 1930. Zur Zytologie der Gattung Torenia sowie einiger Mutanten von T. fournieri. Jahrb. Wissensch. Bot. 72(3): 466-511.

Sobti, S. N. and Singh, S. D. 1961. A chromosome survey of Indian medicinal plants. Part I. Proc. Indian Acad. Sci. Sec. B. 54(3): 138-144.

Srinath, K. V. 1940. Morphological and cytological studies in the genus Calceolaria II. Meiosis in diploid and aneuploid calceolarias. Cytologia 10: 467-491.

Stebbins, G. L., Jenkins, J. A. and Walters, M. S. 1953. Chromosome and phylogeny in Compositae, tribe Cichorieae. Univ. Calif. Publ. Bot. 26(5): 401-430.

Straub, J. 1939. Chromosomenuntersuchungen an polyploiden Blutenpflanzen I. Die Chromatinmasse bei kunstlich-ausgelösten Autopolyploiden. Ber Deutsch Bot. Ges 57(10): 531-544.

Stubbe, H. 1966. Genetik and Zytologie von Antirrhinum L. Sect Antirrhinum. Gustar Fischer Verlag, Jena: $1-421$.

Sngiura, T. 1928a. Chromosome numbers in some higher plants I. Bot. Mag. (Tokyo) 42(503): 504-506.

- 1931. A list of chromosome numbers in Angiospermous plants. Bot. Mag. (Tokyo) 45(535): 353-355.

- 1936b. Studies on the chromosome numbers in higher plants with special reference to cytokinesis I. Cytologia 7(4): 544-595.

Takagi, N. 1938. A list of chromosome numbers in some ornamental plants. Bull. Miyazaki Coll. Agric. Forest. 10: 83-87.

Tandon, S. L. and Bali, P. N. 1958. Morphological and cytological studies on the diploid and the colchicine induced tetraploid in Linaria vulgaris. Genetica 29(1-2): 101-109.

- and Bhutani, K. 1964. Colchicine induced polyploidy in Torenia fownieri Lind. Curr. Sci. 33: 755-756.

Tischler, G. 1934. Die Bedeutungen der Polyploidie für die Verbreitung der Angiospermen, erlautert an den Arten Schleswig-Holsteins mit Ausblicken auf andere Florengebite. Bot. Jahrb. 67: 1-36.

Upcott, M. 1937. The origin and behaviour of chiasmata VII. Eremurus spectabilis. Cytologia 7(1-2): 118130.

Winge, O. 1925. Contributions to the knowledge of chromosome numbers in plants. Cellule 35: 303-324. 